\title{
Development and validation of an instrument to measure family physicians' clinical aptitude in metabolic syndrome in Mexico
}

\author{
Carlos E Cabrera-Pivaral, MD PhD, ${ }^{(1,2)}$ Clara Luz Gutiérrez-Ruvalcaba, MD, ${ }^{(3)}$ \\ Irma Concepción Peralta-Heredia, Psy, ${ }^{(4)}$ Carlos Alonso-Reynoso, MD. ${ }^{(1)}$
}

\begin{abstract}
Cabrera-Pivaral CE, Gutiérrez-Ruvalcaba CL, Peralta-Heredia IC,Alonso-Reynoso C. Development and validation of an instrument to measure family physicians' clinical aptitude in metabolic syndrome in Mexico. Salud Publica Mex 2008;50:457-462.
\end{abstract}

\begin{abstract}
Objective. The purpose of this work was to measure family physicians' clinical aptitude for the diagnosis and treatment of metabolic syndrome in a representative sample from six Family Medicine Units (UMF) at the Mexican Institute for Social Security (IMSS), in Guadalajara, Jalisco, México. Material and Methods. This is a cross-sectional study. A validated and structured instrument was used, with a confidence coefficient (Kuder-Richardson) of 0.95, that was applied to a representative sample of 90 family physicians throughout six UMFs in Guadalajara, between 2003 and 2004. MannWhitney's $U$ and Kruskal-Wallis' tests were used to compare two or more groups, and the Perez-Viniegra Test was used to define aptitude development levels. Results. No statistically significant differences were found in aptitude development between the six family medicine units groups and other comparative groups. Conclusions. The generally low level of clinical aptitude, and its indicators, reflects limitations on the part of family physicians at the IMSS in Jalisco to identify and manage metabolic syndrome.
\end{abstract}

Key words: aptitude, metabolic $\mathrm{X}$ syndrome, education, Mexico
Cabrera-Pivaral CE, Gutiérrez-Ruvalcaba CL, Peralta-Heredia IC,Alonso-Reynoso C.

Desarrollo y validación de un instrumento para medir la aptitud clínica de médicos familiares en síndrome metabólico en México.

Salud Publica Mex 2008;50:457-462.

\section{Resumen}

Objetivo. El propósito de este estudio fue medir la aptitud clínica de los médicos familiares de una muestra representativa de seis Unidades de Medicina Familiar (UMF) del Instituto Mexicano del Seguro Social (IMSS), en Guadalajara, Jalisco, México, en el diagnóstico y tratamiento del síndrome metabólico. Material y Métodos. Es un estudio observacional, prospectivo y comparativo. Se diseñó y validó un instrumento estructurado con un coeficiente de confianza (Kuder-Richardson) de 0.95, aplicado a una muestra representativa de 90 médicos familiares de seis UMF en Guadalajara, entre 2003 y 2004. Se utilizaron los tests de Mann-Whitney U y Kruskal-Wallis para comparar dos o más grupos, y el test de Pérez-Viniegra se utilizó para definir los niveles de desarrollo de aptitud. Resultados. No se observaron diferencias significativas en el desarrollo de aptitud entre las seis UMF. Conclusiones. El bajo nivel general de aptitud clínica refleja las limitaciones para identificar y manejar el síndrome metabólico por parte de los médicos familiares.

Palabras clave: aptitud, síndrome X metabólico, educación, México

(I) Unidad de Investigación en Epidemiología Clínica, Hospital de Especialidades, Centro Médico Nacional de Occidente, Instituto Mexicano del Seguro Social, Guadalajara, México.

(2) Centro de estudios en salud, población y desarrollo humano, Departamento de Ciencias Sociales, Centro Universitario de Ciencias de la Salud, Universidad de Guadalajara, Guadalajara, México.

(3) Coordinación Delegacional de Educación en Salud. Instituto Mexicano del Seguro Social, Guadalajara, México.

(4) Centro de Investigación educativa y formación docente (CIEF), delegación Jalisco. 
$\mathrm{M}$ etabolic Syndrome (MS) has been called the 21st century epidemic. This is due to the fact that in the past 10 years different countries have described an increase in the incidence of this syndrome in pediatric and teenage patients. ${ }^{1}$ This syndrome has been recognized in medical literature since the last century. The combination of metabolic disorders now known as MS was first described by Kylin in the 1920s as the clustering of hypertension, hyperglycaemia, and gout. Since then, it has received different names, such as Syndrome $X$ or insulin resistance syndrome. ${ }^{2}$

The definition of metabolic syndrome depends on which group of experts is doing the defining. All groups agree on the core components of MS: obesity, insulin resistance, dyslipidaemia, and hypertension. However, they provide different clinical criteria to identify such a cluster. Guidelines from the 2001 National Cholesterol Education Program Adult Treatment Panel (ATP III) define MS as any three of the following characteristics in the same individual:

1. Abdominal obesity: waist circumference over $102 \mathrm{~cm}$ (40 in) in men and over $88 \mathrm{~cm}$ (35 in) in women.

2. Fasting blood glucose of $110 \mathrm{mg} / \mathrm{dl}$ or above.

3. Serum triglycerides $150 \mathrm{mg} / \mathrm{dl}$ or above.

4. HDL cholesterol $40 \mathrm{mg} / \mathrm{dl}$ or lower in men and $50 \mathrm{mg} / \mathrm{dl}$ or lower in women.

5. Blood pressure of $130 / 85$ or above. ${ }^{3}$

However, the World Health Organization (WHO) has slightly different criteria for metabolic syndrome:

1. High insulin levels, an elevated fasting blood glucose, or an elevated post meal glucose only with at least two of the following criteria:

a) Abdominal obesity as defined by a waist to hip ratio of greater than 0.9 ,

b) a body mass index of at least $30 \mathrm{~kg} / \mathrm{m}^{2}$ or

c) a waist measurement over 37 inches.

2. Cholesterol panel showing a triglyceride level of at least $150 \mathrm{mg} / \mathrm{dl}$ or HDL cholesterol lower than 35 $\mathrm{mg} / \mathrm{dl}$.

3. Blood pressure of $140 / 90$ or above (or receiving treatment for high blood pressure). ${ }^{3}$

In Mexico, MS prevalence among adults is high (greater than that for the Caucasian population). ${ }^{4}$ If we apply the criteria given by the World Health Organization (WHO), more than six million Mexicans suffer from it, and more than 14 million if we apply the criteria from the National Cholesterol Education Program (ATP III). ${ }^{5}$
MS is a group of health problems that appear simultaneously or sequentially in the patient and lead to a larger risk of presenting type 2 diabetes mellitus and cardiovascular diseases, two of the main causes of morbidity and mortality worldwide. ${ }^{6}$

The main components of MS are abdominal obesity, arterial hypertension, glucose intolerance, and dyslipidemia (high plasma triglycerides and low HDL cholesterol). In addition, it has been proven that inadequate alimentation and the absence of physical activity favor the development of insulin resistance (a parameter for the diagnosis of MS proposed by WHO). ${ }^{5}$ It has also been proven that weight loss is the only intervention that improves all the risk factors for MS.7,8

This pathology requires the family physician's timely identification and integrative clinical management of the syndrome. Clinical aptitude is defined by the ability to know risk factors and develop diagnostic integration and management strategies. ${ }^{9,10}$

The development of clinical aptitude involves the identification of the signs and symptoms of MS, the integration and use of diagnostic and therapeutic resources, and observation of Iatrogenic effects (by commission and omission). ${ }^{11}$

Our findings on family physicians' clinical aptitude is based on a validated instrument developed from actual case reviews of Family Medicine Units charts in order to identify and evaluate the physicians' clinical practices. $^{12}$

\section{Material and Methods}

This is a cross-sectional study that included a total of 450 family physicians from the Family Medicine Units at the Mexican Institute of Social Security (IMSS, in Spanish) in the city of Guadalajara. The sample was obtained by performing a random sample of conglomerates. In the first stage, a random sample to select 6 of the $23(26 \%)$ Family Medicine Units was performed using simple random sampling. In the second stage, 90 family physicians from the previously selected Units were evaluated by census. Inclusion criteria were being an attending physician or replacement physician, working the day shift, either gender, and verbally agreeing to participate in the study by answering the total number of questions. Exclusion criteria were family physicians from the emergency room, working the night shift, being on vacation, having the day off, or being a resident at the moment at which the instrument was administered. Elimination criteria were answering less than $90 \%$ of the questions. ${ }^{13}$

The main study variable was clinical aptitude for MS, defined as the group of abilities expressed by the 
identification of signs, indicators for the use of integrated diagnostics, and the use of resources for diagnosis and treatment. Aptitude was rated using five indicators: 1) Risk factor identification: the identification of the condition, characteristics, or attributes that relate to a major probability of presenting MS, 2) Clinical and paraclinical recognition of MS: the identification of signs as well as laboratory tests suggesting MS, 3) Integrated diagnosis: the gathering of clinical and paraclinical data that determine MS, 4) Global use of diagnostic resources: the ability to use and interpret laboratory and imaging tests that contribute to a better interpretation of MS, 5) Global use of therapeutic resources: the ability to use pharmacological and non-pharmacological means to improve a patient's condition, cure MS, or diminish the probabilities of major damage.

Other study variables were: a) sociodemographic characteristics such as age and sex, b) working conditions such as specialty, shift, years of service, contract type, and department and c) continuous education; that is, previous courses in MS.

Instruments: The instrument was developed and conceptualized by the two authors of this report using case report reviews, based on a participative education perspective that integrates theory and practice, with abilities related to the analysis, synthesis, and critique of clinical situations. The clinical case reports are real, condensed and fragmented in order to reproduce, as faithful as possible, the clinical reality. The questions had three answer options: true, false, and I don't know.

The final version was developed after a validation process by expert family medicine opinions, established by a coincidence of four or five out of five. The instrument had 158 questions distributed by their theoretic values: 27 for risk factor identification, 30 for clinical and paraclinical recognition of MS, 32 for Integrated diagnosis, 28 for global use of diagnostic resources, and 41 for global use of therapeutic resources. Questions were balanced in a 50\% to 50\% ratio between true or false. For qualification purposes each right answer added one point, each wrong answer reduced one point, and the "I don't know" answer had a 0 point value. The result was obtained by the arithmetical addition of right and wrong answers with a maximum theoretical qualification of 158. In order to avoid bias due to a high probability to guess the right answer (50\%) in this type of instrument, the chance-corrected qualifications were calculated, then the following levels of clinical aptitude were established: chance-corrected $(<24)$, very low (25$50)$, low (51-77), intermediate (78-104), high (105-131), and very high (132-158).
Statistical analysis: Kuder-Richardson was used to obtain reliability.

$$
\alpha=\frac{K}{K-1}\left[1-\frac{\sum_{i=1}^{N} p_{i} q_{i}}{\sigma^{2} X}\right]
$$

Descriptive statistics were used with medians, frequency, and percentages. Finally, inferential nonparametric statistics were used with Mann-Whitney's $\mathrm{U}$ test for two unrelated groups and Kruskal-Wallis test was applied to compare more than two unrelated groups. Data was analyzed with EPI-Info 2002 and SPSS 12.

Ethical considerations: In Mexican law, according to the "Ley General de Salud en Materia de Investigación para la Salud" 14 the present work is considered to be research without risk (Article 12). Verbal informed consent from each participant was requested (Article 13).

\section{Results}

The instrument's confidence coefficient (Kuder-Richardson) was 0.95 . General characteristics of the sample are described in Table I, and the number of Family Medicine Units as well as distribution by sex are in Table II. Results sorted by medians for the six Family Medicine Units are also described in Table II; there are no statistically significant differences between groups $(p=0.493)$. Table III shows the clinical aptitude level sorted by Family Medicine Unit, showing that $54.4 \%$ were due to chance and the remaining $45.6 \%$ had a very low level. Global results showed a mean of 23 points in a range of -3 to 50 . Only units B and F obtained a very low level, compared with the answers obtained by chance from the other units $(p=0.376)$. In Table IV, clinical aptitude is sorted by Family Medicine Unit. Table V shows the clinical aptitude level sorted by those who had previous courses in MS and those who did not. Comparing medians between units (A, B, C, D, E, F) and clinical aptitude indicators, no statistically significant differences were found (KW: Non significant). Using the theoretical total for each indicator, no statistically significant difference was found $(p>0.05)$.

When we related clinical aptitude for the identification of MS with sex (U: $p=0.858)$, years of service (KW, $p=0.664$ and $p=0.875$ ), family medicine specialty (U: $p=0.101$ ) and shift (U: $p=0.619$ and 0.897 ), no statistically significant differences appeared.

\section{Discussion}

MS impacts individual, familial, and institutional health. Costs associated with treatment and complications rep- 
Table I

Measurement of Physician's aptitude in MS. General CHARACTERISTICS OF FAMILY PHYSICIANS. GUADALAJARA, JALISCO, 2003-2004

\begin{tabular}{|c|c|c|c|}
\hline Variable & Frequency & $\%$ & Mean (SD) Limits \\
\hline Gender & 53 & 58.9 & \\
\hline Masculine & 36 & 40 & \\
\hline Feminine & I & I.I & \\
\hline Undocumented & 90 & 100 & \\
\hline
\end{tabular}

\begin{tabular}{lrrrr} 
Age group & & & $47.3(5.4)$ & $28-58$ \\
\hline $28-38$ years & 5 & 5.5 & \\
\hline $39-49$ years & 44 & 48.9 & \\
\hline $50-58$ years & 33 & 36.7 & \\
\hline Undocumented & 8 & 8.9 \\
\hline Total & 90 & 100
\end{tabular}

Contract type

\begin{tabular}{lrc}
\hline Attending & 86 & 95.6 \\
\hline Replacement & 2 & 2.2 \\
\hline Undocumented & 2 & 2.2 \\
\hline Total & 90 & 100
\end{tabular}

Family Medicine specialty

\begin{tabular}{lrc}
\hline Yes & 59 & 65.5 \\
\hline No & 28 & 31.1 \\
\hline Undocumented & 3 & 3.3 \\
\hline Total & 90 & 100
\end{tabular}

Years of practice

I7.7(6.I) $\quad 2.0-27$

\begin{tabular}{lcl}
\hline$<10$ years & 9 & 10 \\
\hline $10-19$ years & 35 & 38.9 \\
\hline$>20$ years & 36 & 40 \\
\hline Undocumented & 10 & 11.1 \\
\hline Total & 90 & 100
\end{tabular}

Shift

\begin{tabular}{lcc} 
Shift & & \\
\hline Morning & 59 & 65.6 \\
\hline Afternoon & 31 & 34.4 \\
\hline Total & 90 & 100
\end{tabular}

Previous courses in metabolic syndrome

\begin{tabular}{lcc}
\hline Yes & 23 & 25.6 \\
\hline No & 65 & 72.2 \\
\hline Undocumented & 2 & 2.2 \\
\hline Total & 90 & 100
\end{tabular}

Table II

MeAsurement of Physician's aptitude in MS. Family

Medicine Units and Qualifications. Guadalajara, JALISCO, 2003-2004

\begin{tabular}{|c|c|c|c|c|c|c|c|}
\hline \multirow[b]{2}{*}{ Medicine Unit } & \multicolumn{2}{|c|}{ Masculine } & \multicolumn{2}{|c|}{ Feminine } & \multirow[b]{2}{*}{ Total } & \multirow[b]{2}{*}{$\%$} & \multirow[t]{2}{*}{$\begin{array}{l}\text { Qualification } \\
\text { (median) } \pm\end{array}$} \\
\hline & $n$ & $\%$ & $n$ & $\%$ & & & \\
\hline A & 3 & 3.3 & 3 & 3.3 & 6 & 6.7 & 24 \\
\hline$B$ & 10 & 11.1 & 8 & 8.8 & 19 & 21 & 28 \\
\hline $\mathrm{C}$ & 14 & 15.5 & II & 12.2 & 25 & 27.8 & 17 \\
\hline D & 6 & 6.6 & 3 & 3.3 & 9 & 10 & 23 \\
\hline $\mathrm{E}$ & 12 & 13.3 & 4 & 4.4 & 16 & 17.8 & 22 \\
\hline $\mathrm{F}$ & 8 & 8.8 & 7 & 7.7 & 15 & 16.7 & 29 \\
\hline Total & 53 & 58.6 & 36 & 39.7 & $90 *$ & & \\
\hline \multicolumn{3}{|c|}{$\begin{array}{l}* \text { I case undocumented } \\
\pm \text { Kruskal-Wallis } p=0.493\end{array}$} & & & & & \\
\hline
\end{tabular}

resent a serious burden on health services and patients. This is the reason why family physicians, being the first level in health care, should act with efficacy and in a timely manner. Research into the development of clinical aptitude of family physicians in MS should be mandatory.

The measurement of clinical aptitude with instruments like the one we have used is generally used to identify clinical aptitude and the degree of transition between novice and expert. This is done with the objective of promoting educational processes that lead to increasing expertise as a result of intentional educational processes..$^{15}$

Education for family medicine specialists seeks to provide theoretical and methodological tools for physicians ${ }^{16}$ to offer health care to the population, the identification and treatment of MS being one of these tools; however, the results of our study indicate that there is no relation between the tools provided and the ability of physicians to diagnose the syndrome, given the low aptitude level found in the total sample. Results sorted by curricular differences suggest a slight advantage, but is not significant.

In addition, years of practice in family medicine should give the physician vast experience in situations and conditions in the health care of the population. Physicians with more than 20 years in practice showed a slight non-statistically significant advantage in clinical aptitude for MS, in contrast with the other groups. 
Table III

Measurement of physician's aptitude in MS. LeVel by Family Medicine Unit, Guadalajara, Jalisco, 2003-2004

\begin{tabular}{|c|c|c|c|c|c|c|c|c|c|c|c|c|c|c|}
\hline \multirow[b]{3}{*}{ Aptitude Level } & \multicolumn{10}{|c|}{ Family Medicine Unit } & & \\
\hline & \multicolumn{2}{|c|}{$A$} & \multicolumn{2}{|c|}{$B$} & \multicolumn{2}{|c|}{$C$} & \multicolumn{2}{|c|}{$D$} & \multicolumn{2}{|c|}{$E$} & & & & \\
\hline & $\overline{n=6}$ & (6.6) & $n=19$ & $(2 I .1)$ & $n=25$ & $(27.7)$ & $n=9$ & $(10)$ & $n=16$ & $(I 7.7)$ & \multicolumn{2}{|c|}{$\frac{F}{n=15 \quad(16.6)}$} & \multicolumn{2}{|c|}{$\frac{G l o D a l}{90 \quad(100)}$} \\
\hline By chance corrected $(0-24)$ & 3 & (3.3) & 9 & (10) & 17 & (I8.8) & 5 & (5.5) & 10 & $(I I . I)$ & 5 & $(5.5)$ & 49 & (54.4) \\
\hline Very low (25-50) & 3 & (3.3) & 10 & $(I I . I)$ & 8 & $(8.8)$ & 4 & (4.4) & 6 & (6.6) & 10 & (II.I) & 41 & (45.6) \\
\hline Low and above (5I-|58) & 0 & & 0 & & 0 & & 0 & & 0 & & 0 & & 0 & \\
\hline
\end{tabular}

Table IV

Physician's clinical aptitude to identify metabolic syndrome, sorted by Family Medicine Unit. GuadalajARA, Jalisco, 2003-2004

\begin{tabular}{|c|c|c|c|c|c|c|c|c|c|}
\hline \multirow{2}{*}{$\begin{array}{l}\text { Family Medicine Unit } \\
\text { Theoretical total }\end{array}$} & \multicolumn{2}{|c|}{$\begin{array}{c}\text { Diagnostic } \\
\text { integration } \\
\text { Median (limits) }\end{array}$} & \multicolumn{2}{|c|}{$\begin{array}{c}\text { Risk } \\
\text { factors } \\
\text { Median (limits) }\end{array}$} & $\begin{array}{l}\text { Clinical and paraclinical } \\
\text { recognition } \\
\text { Median (limits) }\end{array}$ & \multirow[t]{2}{*}{$\begin{array}{c}\text { Global use } \\
\text { of diagnostic resources } \\
\text { Median (limits) }\end{array}$} & \multirow[t]{2}{*}{$\begin{array}{c}\text { Global use } \\
\text { of therapeutic resources } \\
\text { Median (limits) }\end{array}$} & \multirow[t]{2}{*}{$\begin{array}{c}\text { Global } \\
\text { Median (limits) }\end{array}$} & \multirow[t]{2}{*}{$p^{*}$} \\
\hline & 32 & 27 & 30 & 28 & 158 & & & & \\
\hline$A(n=6)$ & 11.5 & $(0-15)$ & 6 & $(2-13)$ & $4.5 \quad(0-9)$ & 9.5 (7-II) & $-5.5(-18-0)$ & $24(10-32)$ & 0.27 \\
\hline$B(n=18)$ & 9 & $(-1-18)$ & 7 & $(-3-10)$ & $6 \quad(-4-16)$ & $12 \quad(-4-15)$ & $-9 \quad(-19-8)$ & $28(19-38)$ & 0.62 \\
\hline$C(n=25)$ & 8 & $(2-19)$ & 5 & $(-5-17)$ & $6 \quad(-2-15)$ & $7 \quad(-1-16)$ & $-7 \quad(-23-13)$ & $17 \quad(6-50)$ & 0.95 \\
\hline$D(n=9)$ & 9 & $(0-14)$ & 7 & $(I-3)$ & $(4-9)$ & II (6-14) & $-4 \quad(-2 \mid-I)$ & 23 (II-37) & 0.15 \\
\hline$E(n=16)$ & 8 & $(-I-144)$ & 6 & $(I-13)$ & $2.5(-3-15)$ & $10 \quad(-1-15)$ & $-6 \quad(-13-1)$ & $22(-3-33)$ & 0.2 \\
\hline$F(n=16)$ & 9 & $(2-18)$ & 7 & $(I-16)$ & $6 \quad(2-14)$ & $8 \quad(3-15)$ & $-4 \quad(-15-\mid I)$ & $29(12-43)$ & 0.45 \\
\hline P* & 0.29 & & 0. & & 0.11 & 0.11 & 0.3 & 0.49 & \\
\hline
\end{tabular}

Table V

Physician's APTITUde LeVel SORTED BY PREVIOUS COURSES IN METABOLIC SYNDROME. GuAdALAJARA, JALISCO, 2003-2004

\begin{tabular}{lccccc} 
Aptitude Level & \multicolumn{3}{c}{ Previous Courses in MS } & & No Previous Courses in MS \\
\cline { 2 - 3 } \cline { 5 - 6 } & $N$ & $\%$ & & N & $\%$ \\
Chance corrected & 13 & 14.4 & & 35 & 38.8 \\
\hline Very Low & 10 & 11.1 & 30 & 33.3 \\
\hline Total & 23 & 25.5 & & 65 & 72.1 \\
$p=0.825$ & & &
\end{tabular}

This fact should motivate the creation of spaces and opportunities for continuous medical education and specialist training. ${ }^{17,18}$

In the matter of working shifts, there were no significant differences in the development of aptitude, although when compared with the afternoon shift, morning shift physicians showed an advantage. This could be related to the fact that most of the continuous educational activities as well as other institutional activities take place during the morning shift, which may have influenced the results. However, this insignificant advantage is also explained by the general tendency of educational processes to follow a traditional model..$^{9,13}$

From the theoretical perspective of our study it would be most convenient to restructure the family physician and general physician's curricula over the medium term. ${ }^{19}$ It would also be of interest that this be done by higher education institutions that train family medicine professionals. ${ }^{20}$

The development of clinical aptitude requires environments that foster reflection on the part of the physician; a revision of educational curriculum; and the development of personal knowledge. The results sug- 
gest that these conditions are lacking, since a very low clinical aptitude reflects a clear inability to investigate and interpret MS.

The identification of risk factors for MS shows that $20 \%$ of physicians had the capacity to investigate them by the development of a diagnostic hypothesis.

The pertinent global use of diagnostic resources was shown in 39\% of family physicians, most of all in the management of clinical tests.

The ability to orientate and propose requires the capacity to judge the pertinence of decisions made in the clinical case reviews, as presented in the instrument, and propose alternative actions. ${ }^{20-22}$ The use of therapeutic resources, implying the ability to give an integrative management of MS, was achieved only by $14.5 \%$ of family physicians.

The advantage of contract type couldn't be evaluated, given that attending physicians represented 95.6\% of the sample. There is a slight advantage for family physicians in a specialty working the morning shift with more than 20 years in practice. However, the global clinical aptitude results were very low for family physicians $(45.6 \%)$, reflecting a limited capacity to deal with MS.

\section{References}

I. Lara E, Carrillo T, Carrasco M. Nutrición en el Síndrome Metabólico. In:Annual Review del Colegio de Medicina Interna de México; Mexico: Intersistemas; 2005.

2. Alberti KG, Zimmet P, Shaw J. Metabolic syndrome-a new worldwide definition. A Consensus Statement from the International Diabetes Federation. Diabetic Medicine 2006;23(5):469-480.

3. Lorenzo C,Williams K, Hunt KJ, Haffner SM. The National Cholesterol Education Program - Adult Treatment Panel III, International Diabetes Federation, and World Health Organization definitions of the metabolic syndrome as predictors of incident cardiovascular disease and diabetes. Diabetes Care 2007;30(I):8-13.

4. Lerman G, Aguilar-Salinas C, Gómez-Pérez F, Reza A, Hernández J, Vázquez CC. El síndrome metabólico, posición de la sociedad Mexicana de nutrición y endocrinología, sobre la definición, fisiopatología y diagnóstico. Características del síndrome metabólico en México. Revista de Endocrinología y Nutrición 2004;12(3): 109-122.
5. Gonzalez C, Sánchez Z, Elizondo A, Malanco H. Inflamación y resistencia a la insulina, su papel en el desarrollo del síndrome metabólico. In:Annual Review del Colegio de Medicina Interna de México. Mexico: Intersistemas, 2005

6. Skilton P, Moulin A, Sérusclat A, Nony P, Bonnet F.A comparison of the NCEP-ATPIII, IDF and AHA/NHLBI metabolic syndrome definitions with relation to early carotid atherosclerosis in subjects with hypercholesterolemia or at risk of CVD: Evidence for sex-specific differences. Atherosclerosis 2007; 190(2):416-422.

7. Rodríguez P, Sánchez L, Martínez V. Síndrome metabólico. Rev Cub Endocrinol 2002; 13(3):238-252.

8. Dekker J, Girmain C, Rhodes T, Nipjels G, Stehouwer CD, Bouter LM. Metabolic Syndrome and 10 year cardiovascular disease risk in the Hoorn study. Circulation 2005; I 2:666-673.

9. Chavez V,Aguilar M. Aptitud clínica en el manejo de la familia, en residentes de Medicina Familiar. Rev Med IMSS 2002;40(6):477-48I. 10. Garfias G,Aguilar M,Viniegra V. Cómo explorar las aptitudes de los médicos residentes de traumatología y ortopedia en traumatismo cráneoencefálico. Rev Med IMSS 1997;(35):233-237.

I I. Cobos AH, Insfrán SMD, Pérez CP, Elizaldi LNE, Hernández DE, Barerra MJ.Aptitud clínica durante el internado de pregrado en hospitales generales. Rev Med IMSS 2004;42(6):469-476.

I2. Sabido $S$, Viniegra V. Competencia y desempeño en la evaluación del médico: estudio con pacientes diabéticos en el primer nivel de atención. In:Viniegra L. La investigación en la educación: papel de la teoría y la observación. Mexico: IMSS, 2000.

13. Gutiérrez G,Aguilar M,Viniegra V.Validación de un instrumento para evaluar la competencia clínica del médico familiar. Rev Med IMSS 200I;37:20I-2I0.

14. Secretaria de Salud: Reglamento de la Ley General de Salud en materia de investigación para la salud. Mexico DF: SSA, 1990.

15. Rothman A, Blackmore D, Cohen R, Reznic R. The consistency and uncertainty in examiners' definitions of pass/fail performance on OSCE stations. Ev Health Prof 1996; 16:322-332.

16. Searle J. Defining competency-the role of standard setting. Med Educ 2000; 34:363-366.

17. Satir V. Psicoterapia familiar conjunta. Mexico City: Prensa Medica, 1986: 86-88

18. Minuchin S. Familias y terapia familiar. Madrid: Gedisa, 1977.

19. Larios M,Trejo M, Cortés G. Evaluación de la competencia clínica. Rev Med IMSS 1998;(36):77-82

20. Gardner W, Nutting PA, Kelleher KJ, Does the family Apgar effectively measure family functioning? Aten Primaria 1996; 17:338-34I.

21. Sánchez T, Pérez C, Navarro L, Kumazagua I,Vásquez Garibay E. Dinámica Familiar: metodología para su evaluación. Am J Dis 1994;7:48-52. 22. Vazquez E, Sánchez T, Navarro L, Romero V, Pérez C, Kumazagua I. Instrumento de Medición de la dinámica de la familia nuclear mexicana. Un enfoque cuantitativo. Bol Med Hosp Infant Mex 2003;60:33-52. 